\title{
The abundance and diversity of butterflies (Lepidoptera: Rhopalocera) in Talaud Islands, North Sulawesi, Indonesia
}

\author{
RONI KONERI ${ }^{1, \bullet}$, MEIS J. NANGOY ${ }^{2, \bullet v}$ PARLUHUTAN SIAHAAN ${ }^{1, \bullet \vee \vee}$ \\ ${ }^{1}$ Department of Biology, Faculty of Mathematics and Natural Sciences, Universitas Sam Ratulangi. J1. Kampus Bahu, Manado 95115, North Sulawesi, \\ Indonesia, Tel./Fax.: +62-431-864386; Fax.: +62-431-85371, •email: ronicaniago@unsrat.ac.id, vvvluhut.siahaan68@unsrat.ac.id \\ ${ }^{2}$ Department of Animal Production, Faculty of Animal Science, Universitas Sam Ratulangi. J1. Kampus Bahu, Manado 95115, North Sulawesi, Indonesia, \\ Tel./Fax.: +62-431-864386; Fax.: +62-431-85371, ^vemail: rmnangoy@unsrat.ac.id,
}

Manuscript received: 8 September 2019. Revision accepted: 22 October 2019.

\begin{abstract}
Koneri R, Nangoy MJ, Siahaan P. 2019. The abundance and diversity of butterflies (Lepidoptera: Rhopalocera) in Talaud Islands, North Sulawesi, Indonesia. Biodiversitas 20: 3275-3283. Butterflies play a number of roles in the ecosystem. They help pollination and natural propagation and also are an important element of the food chain as prey for bats, birds, and other insectivorous animals. This study aimed to analyze the abundance and diversity of butterflies (Lepidoptera: Rhopalocera) in the Talaud Islands of North Sulawesi, Indonesia. The sampling method used was scan sampling along the transect line in three habitat types, namely, forest edge, farmland, and shrubland. The species diversity was determined by using the diversity index (Shanon-Wiener), the species richness index was calculated using the Margalef species richness index (R1), while species evenness was counted by using the Shannon evenness index (E). One-way ANOVA and Duncan test at the 95\% significance level were used to determine differences in species richness, species abundance, species diversity values, and species evenness among habitat. In this study, we identified 1008 individuals of butterfly consisted of 32 species and five families. Nymphalidae was the dominant family with 15 species, while the highest abundance species was Eurema tominia. The highest species abundance, species richness index, species diversity index, and species evenness index were found in forest edge habitat. The largest similarity index of the composition of the butterfly communities was found in forest edge and farmland habitats. The abundance and diversity of butterfly species in a habitat are strongly influenced by the diversity of vegetation as shelter and source of nectar for butterflies, and the existence of a river as a source of water and minerals from wet rocks, mud, and sand along the riverside.
\end{abstract}

Keywords: Butterfly, species abundance, species diversity, habitat type, sampling scan, Talaud Islands

\section{INTRODUCTION}

Talaud Islands are located in Wallacea, a biogeographical region that has a high diversity of varies endemic species, many of those endemic species are endangered. Currently, there are 557 species of butterflies from the order of Lepidoptera in the Sulawesi Island and surrounding area. Butterfly species endemicity in Sulawesi Island reaches $40 \%$. This endemicity level is higher than those in other islands in Indonesia, except for Papua that has a butterfly endemicity level of $46 \%$ (Vane-Wright and de Jong 2003).

Butterfly is insect belonging to the order of Lepidoptera that has scaly wings. They are beautiful animals and have an attractive shape (Arya et al. 2014). Their beautiful and colorful patterns of wings cause butterflies to become one of the beautiful animals that attract attention, and many are collected as ornaments (Noerdjito and Aswari 2003).

Butterflies have a wide distribution and occupy various habitats (Aguirre-Gutierrez et al. 2017). These insects are part of the food chain, acting as the first-level consumer and prey for predators. Predators of butterflies are birds, frogs, monkeys, snakes, rats, bats, spiders, and beetles (Miller and Hammond 2007). Butterfly also plays a role in the process of pollination (Abrol 2012; Patil et al. 2017; Martínez-Adriano et al. 2018). The other role of the butterfly is as a bioindicator of environmental quality (Widhiono 2004; Thomas 2005). Therefore, butterfly is one of the most studied invertebrate groups (Merckx et al. 2013).

The abundance and diversity of butterfly in a habitat are highly dependent on various factors, such as the availability of host and larval food plants, the structure of vegetation complexity, and predators (Patil et al. 2017). Habitat changes by various environmental damages caused by human activities, such as logging (Hill 1999) and landuse change (Posha and Sodhi 2006; Koh 2007; Harmonis and Saud 2017), will have an impact on the abundance and diversity of butterfly.

Increasing population and development in the Talaud Islands, North Sulawesi, will affect the increasing land use. Land use will lead to the conversion of forests into residential areas and plantations. As a consequence, it will change the structure of vegetation complexity and will have an impact on the abundance and diversity of butterflies in the islands. Meanwhile, the abundance and diversity of butterflies in the Talaud Islands of North Sulawesi have never been studied and published. Therefore, this study aimed to analyze the abundance and diversity of butterflies (Lepidoptera; Rhopalocera) in the Talaud Islands of North Sulawesi, Indonesia. 


\section{MATERIALS AND METHODS}

\section{Study area}

This study was conducted in the Talaud Islands, North Sulawesi, Indonesia, from March to June 2018 (Figure 1). The sampling of butterflies was conducted in three types of habitat, namely, forest edge, farmland, and shrubland (Figure 2).

\section{Sampling methods}

In each habitat type, three transect lines were installed with a length of $500 \mathrm{~m}$. The sampling was conducted by surveying the transect line using a scan sampling method (Pollard 1977; Martin and Bateson 1993). It was conducted monthly for 4 months from 8.00-15.00 WITA and three days of observation in each month. Butterflies that could not be identified immediately on the field were captured using butterfly nets (sweep net) and put into papillote paper for identification purposes in the laboratory. The identification of butterflies based on identification books by Peggie (2011; 2014), Van-Wright and de Jong 2003, and Butterflies of the South East Asian Island, Part I
Papilionidae, Part II Pieridae-Danaidae, Part III SatyridaeLybytheidae, Part IV Nymphalidae (I), Part V Nymphalidae (II) (Tsukada and Nishiyama 1982; 1981; 1982; 1985; 1991).

\section{Environmental measurement methods}

Air temperature, air humidity, canopy closure, altitude, and coordinates were measured for environmental data. Air temperature and humidity were measured using thermohygrometer. Plotting methods were used for counting the percentage of canopy closure. In each habitat was obtained 4 plots and the size of each plot was $20 \mathrm{~m} \times 20 \mathrm{~m}$. The percentage of canopy closure in each plot was obtained by vertically projecting tree canopy closure on the plot. Vertical projection on the flat area of the land was then converted into a percentage, with the area of the plot as the denominator, so that the value of canopy closure will be obtained for each plot in each transect. Altitude and coordinates were measured using the Global Positioning System (GPS) on each transect line.

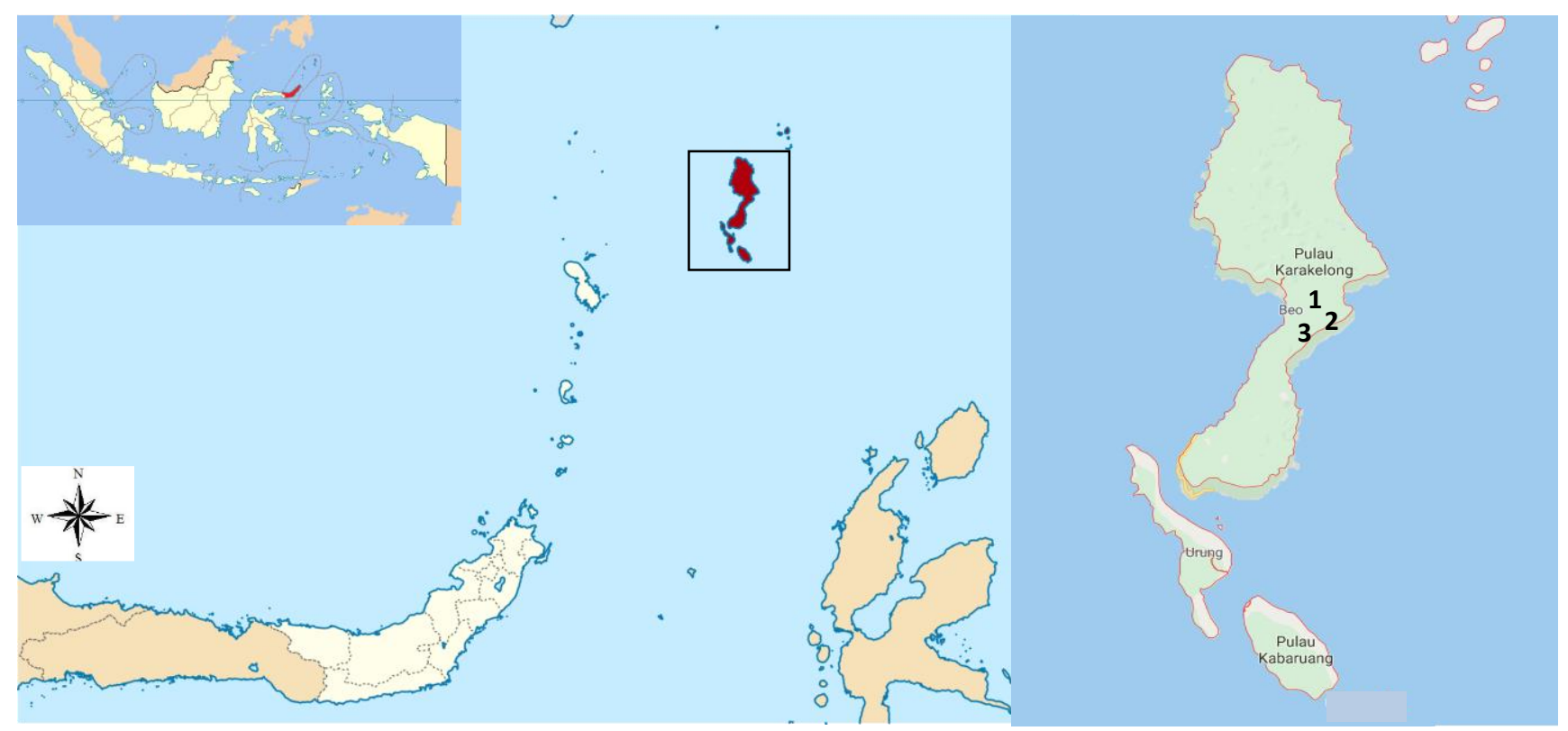

Figure 1. Map of the study area in Talaud Islands, North Sulawesi, Indonesia. Note: 1. Forest edge, 2. Farmland, 3. Shrubland (Google Maps, 2019)

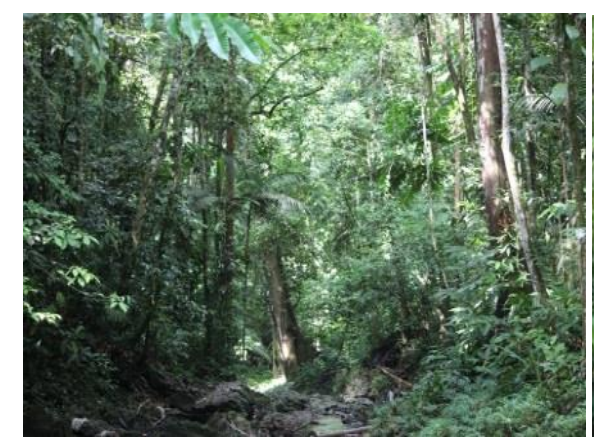

A

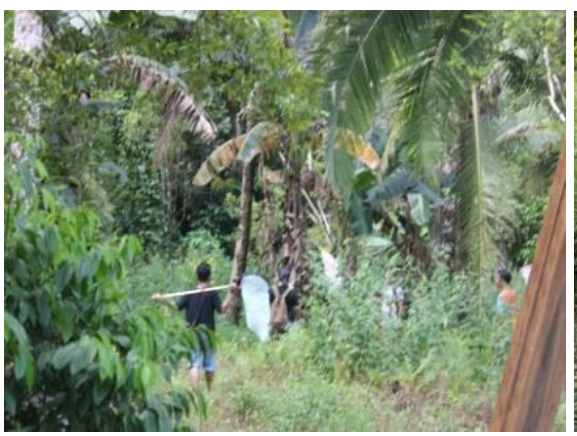

B

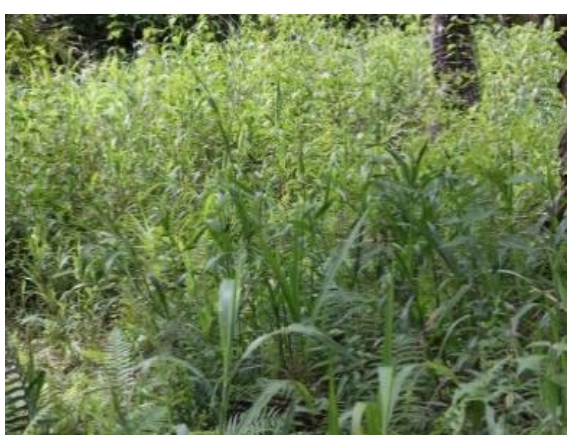

C

Figure 2. Photographs of study sites in Talaud Islands, North Sulawesi, Indonesia. A. Forest edge, B. Farmland, C. Shrubland 


\section{Data analysis}

The species richness index was calculated by using Margalef species richness index (R1) with the formula:

$$
\mathrm{R} 1=(\mathrm{S}-1) / \operatorname{LogN} \text { (Kannagi et al. 2016) }
$$

Meanwhile, species diversity index $(\mathrm{H})$ was determined by using the Shannon-Weiner diversity index with the formula as follows:

$$
\left(\mathrm{H}^{\prime}\right)=-\sum_{i=l}^{s}\left(\mathrm{P}_{\mathrm{i}}\right)\left(\ln \mathrm{P}_{\mathrm{i}}\right)
$$

Where: $\mathrm{Pi}=$ Proportion of each species $\ln =$ Natural logarithm (natural number) (Magurran 1988).

The calculation of species evenness used the Shannon evenness index (E) with the following formula:

$$
\mathrm{E}=\mathrm{H} / \ln (\mathrm{S})
$$

Where: $S=$ Number of species (Magurran 2004).

Data were analyzed by using the Statistica program version 6. One-way ANOVA and Duncan test at the 95\% significance level were used to determine differences in species richness, species abundance, species diversity values, and species evenness among habitat (StatSoft 2001; Ohsawa 2005). In order to understand the similarity of the butterfly community in several different habitats, the Sørensen similarity index was used, and the data were about the presence and absence of butterfly species (Magguran 1988). The index was calculated using Excel. Dissimilarity value (1-Sørensen index) was employed for cluster analysis Krebs 1999; Ludwig and Reynold 1988).

Cluster analysis of each community was arranged hierarchically in the form of dendrograms created using the Statistica program for Windows 6 (StatSoft 2001). Clustering process employed the unweighted pair group method with arithmetic mean (UPGMA) and Euclidean distance (Lewis 2001).

\section{RESULTS AND DISCUSSION}

\section{Butterfly species abundance}

In this present study, a total of 1008 individuals belonging to 32 species and 5 families were identified and recorded. Of them, 12 species were found in all habitat types, while seven species were only found in forest edge and two species were only found in farmland (Table 1). The families found were Nymphalidae, Papilionidae, Lycaenidae, Pieridae, and Hesperiidae. Nymphalidae was the most dominant family with 15 species and 416 individuals $(41.27 \%)$ followed by Pieridae with 7 species and 297 individuals (29.46\%). Nymphalidae was a family that was dominantly found in all habitat types. Hesperiidae was the family with the least number of species found, only one species and two individuals $(0.20 \%)$. The Hesperiidae family was only found in forest edge and was not found in farmland and shrubland (Figure 3). The highest abundance species was Eurema tominia (22.12\%) followed by Junonia hedonia intermedia (13.79\%), and the lowest was Papilio ascalaphus and Pithecops phoenix with only one individual was found for each species $(0.20 \%)$ (Table 1 and Figure 3).

\section{The abundance and diversity of butterfly species}

Comparing to the farmland and shrubland, forest edge had the highest species abundance, species richness index, species diversity index, and species evenness index (Figure 4). One-way ANOVA and Duncan test showed that there were significant differences in species abundance, richness index, and species diversity index in three habitats studied, while species evenness did not show significant differences $(\mathrm{P}<0.05)$ (Figure 4).
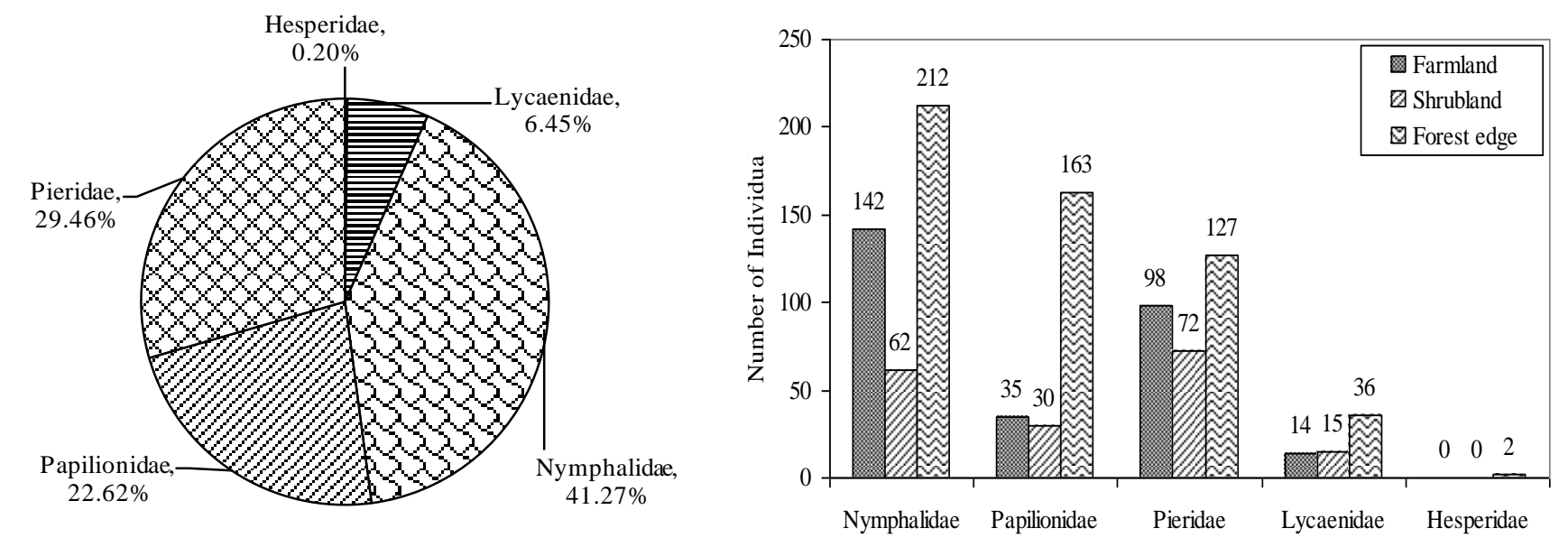

Figure 3. The abundance of family butterflies found in three types of habitat at Talaud Islands, North Sulawesi, Indonesia 
Table 1. Number of family, species and individual butterflies found in three types habitat from Talaud Islands, North Sulawesi, Indonesia

\begin{tabular}{|c|c|c|c|c|c|}
\hline \multirow[b]{2}{*}{ Family/species } & \multicolumn{4}{|c|}{ Number of Individuals Grand } & \multirow[b]{2}{*}{$\%$} \\
\hline & $\begin{array}{c}\text { Farm } \\
\text { land }\end{array}$ & $\begin{array}{c}\text { Forest } \\
\text { edge }\end{array}$ & $\begin{array}{c}\text { Shrub } \\
\text { land }\end{array}$ & Total & \\
\hline \multicolumn{6}{|l|}{ Nymphalidae } \\
\hline Junonia hedonia intermedia & 42 & 75 & 22 & 139 & 13.79 \\
\hline Orsotriaena medus & 26 & 14 & 20 & 60 & 5.95 \\
\hline Euploea leucostictos westwoodi & 14 & 28 & 1 & 43 & 4.27 \\
\hline Ideopsis juventa tontoliensis & 3 & 30 & 8 & 41 & 4.07 \\
\hline Hypolimnas bolina & 8 & 18 & 2 & 28 & 2.78 \\
\hline Mycalesis horsfieldii & 15 & 0 & 9 & 24 & 2.38 \\
\hline Cupha arias & 15 & 4 & 0 & 19 & 1.88 \\
\hline Danaus affinis fulfarata & 0 & 13 & 0 & 13 & 1.29 \\
\hline Euploea algea & 5 & 6 & 0 & 11 & 1.09 \\
\hline Vindula celebensis & 5 & 6 & 0 & 11 & 1.09 \\
\hline Danaus ismare alba & 9 & 0 & 0 & 9 & 0.89 \\
\hline Idea leuconoe & 0 & 6 & 0 & 6 & 0.60 \\
\hline Faunis manado & 0 & 5 & 0 & 5 & 0.50 \\
\hline Hypolimnas misippus & 0 & 5 & 0 & 5 & 0.50 \\
\hline Yoma sabina & 0 & 2 & 0 & 2 & 0.20 \\
\hline \multicolumn{6}{|l|}{ Papilionidae } \\
\hline Graphium agamemnon & 17 & 83 & 20 & 120 & 11.90 \\
\hline Papilio polytes & 1 & 65 & 2 & 68 & 6.75 \\
\hline Papilio rumanzovia & 4 & 10 & 8 & 22 & 2.18 \\
\hline Papilio sataspes & 12 & 5 & 0 & 17 & 1.69 \\
\hline Papilio ascalaphus & 1 & 0 & 0 & 1 & 0.10 \\
\hline \multicolumn{6}{|l|}{ Pieridae } \\
\hline Eurema tominia & 78 & 81 & 64 & 223 & 22.12 \\
\hline Gandaca harina & 16 & 4 & 0 & 20 & 1.98 \\
\hline Eurema blanda & 0 & 14 & 2 & 16 & 1.59 \\
\hline Eurema hecabe & 0 & 10 & 5 & 15 & 1.49 \\
\hline Catopsilia pomona flava & 2 & 9 & 0 & 11 & 1.09 \\
\hline Hebomoia glaucippe celebensis & 1 & 7 & 1 & 9 & 0.89 \\
\hline Appias zarinda & 1 & 2 & 0 & 3 & 0.30 \\
\hline \multicolumn{6}{|l|}{ Lycaenidae } \\
\hline Jamides celeno & 10 & 27 & 6 & 43 & 4.27 \\
\hline Jamides snelleni & 4 & 8 & 4 & 16 & 1.59 \\
\hline Euchrysops cnejus & 0 & 0 & 5 & 5 & 0.50 \\
\hline Pithecops phoenix & 0 & 1 & 0 & 1 & 0.10 \\
\hline \multicolumn{6}{|l|}{ Hesperidae } \\
\hline \multirow[t]{2}{*}{ Potanthus fettingi } & 0 & 2 & 0 & 2 & 0.20 \\
\hline & 289 & 540 & 179 & 1008 & 100.00 \\
\hline
\end{tabular}

Species abundance at farmland was not significantly different from species abundance in shrubland, but was significantly different from that one in forest edge. The richness index and the diversity index of butterfly species in farmland were not significantly different from those in forest edge, whereas the diversity indices in farmland and forest edge were significantly different from the shrubland (Figure 4).

\section{The similarity of the butterfly community in Talaud}

The largest similarity index of butterflies in different habitat was between forest edge habitat and farmland habitat $(76 \%)$. The smallest Sørensen similarity index of the butterfly community was between forest edge habitat and shrubland habitat (64\%) (Table 4). Based on the results of the dendrogram using unweighted pair group method with arithmetic mean (UPGMA), there were two clades, the first is forest edge and farmland habitat, and the second is shrubland. Shrubland habitat is substantially different from forest edge and farmland habitat (Figure 5). This result showed that the composition of the butterfly community in forest edge habitat had many similarities with farmland.

\section{Correlation of butterfly species diversity with environmental factors}

In this study, environmental factors, such as air humidity, air temperature, canopy closure, and altitude were measured. Based on the data, air temperature in shrubland was higher than in forest edge and farmland. The highest value of air humidity and the percentage of canopy closure is in the forest edge habitat while the lowest ones were in shrubland habitat (Table 3).

Table 2. Matrix about butterflies community similarity among habitats in Talaud Islands, North Sulawesi, Indonesia

\begin{tabular}{llll}
\hline Habitat & Farmland & Forest edge & $\begin{array}{l}\text { Shrublan } \\
\text { d }\end{array}$ \\
\hline Farmland & 1.00 & 0.76 & 0.68 \\
Forest edge & 0.76 & 1.00 & 0.64 \\
Shrubland & 0.68 & 0.64 & 1.00 \\
\hline
\end{tabular}

Table 3. The environmental factor in three types of habitat at Talaud Islands, North Sulawesi, Indonesia

\begin{tabular}{|c|c|c|c|c|c|c|c|}
\hline \multirow{2}{*}{ Habitat } & \multirow{2}{*}{ Transect } & \multirow{2}{*}{$\begin{array}{c}\text { Temperature } \\
\left({ }^{\circ} \mathrm{C}\right)\end{array}$} & \multirow{2}{*}{$\begin{array}{c}\text { Humidity } \\
(\%)\end{array}$} & \multirow{2}{*}{$\begin{array}{c}\text { Canopy } \\
(\%)\end{array}$} & \multirow{2}{*}{$\begin{array}{c}\text { Altitude } \\
\text { (m asl) }\end{array}$} & \multicolumn{2}{|c|}{ Coordinates } \\
\hline & & & & & & $\mathbf{S}$ & $\mathbf{E}$ \\
\hline Farmland & 1 & 30.0 & 81.0 & 75.0 & 86.0 & $04.13 .46 .68 "$ & $126.50 .05 .43^{\prime \prime}$ \\
\hline Farmland & 2 & 30.0 & 76.0 & 70.0 & 80.0 & 04.13.08.34" & $126.50 .09 .57 "$ \\
\hline Farmland & 3 & 30.5 & 78.0 & 80.0 & 86.0 & $04.13 .25 .06 "$ & $126.50 .10 .93 "$ \\
\hline Farmland & 4 & 31.5 & 79.0 & 70.0 & 87.0 & $04.13 .20 .46^{\prime \prime}$ & 126.49.58.73" \\
\hline Average \pm SD & & $30.5 \pm 0.7$ & $78.5 \pm 2.1$ & $73.8 \pm 4.8$ & $84.6 \pm 3.2$ & & \\
\hline Forest edge & 1 & 28.5 & 85 & 85.00 & 101 & 04.13.35.44" & 126.48.40.75" \\
\hline Forest edge & 2 & 29.1 & 81 & 80.00 & 90 & $04.13 .40 .05^{\prime \prime}$ & 126.48.38.06" \\
\hline Forest edge & 3 & 29.4 & 83 & 85.00 & 84 & $04.13 .33 .82 "$ & 126.48.41.16" \\
\hline Forest edge & 4 & 29.9 & 87 & 85.00 & 92 & $04.13 .28 .05^{\prime \prime}$ & 126.48.41.20" \\
\hline Average $\pm S D$ & & $29.2 \pm 0.6$ & $84.0 \pm 2.6$ & $83.8 \pm 2.5$ & $91.8 \pm 7.0$ & & \\
\hline Shrubland & 1 & 33.4 & 57 & 40.00 & 62 & 04.13'.49.77" & $126.48^{\prime} .33 .30^{\prime \prime}$ \\
\hline Shrubland & 2 & 32.5 & 65 & 45.00 & 48 & $04.13 .28 .66 "$ & 126.48.40.20" \\
\hline Shrubland & 3 & 32.2 & 55 & 50.00 & 59 & $04.13 .26 .24 "$ & 126.48.37.74" \\
\hline Shrubland & 4 & 33.7 & 62 & 55.00 & 82 & $04.13 .20 .45^{\prime \prime}$ & 126.48.37.53" \\
\hline Average \pm SD & & $32.9 \pm 0.7$ & $59.8 \pm 4.8$ & $47.5 \pm 6.5$ & $62.8 \pm 14.2$ & & \\
\hline
\end{tabular}



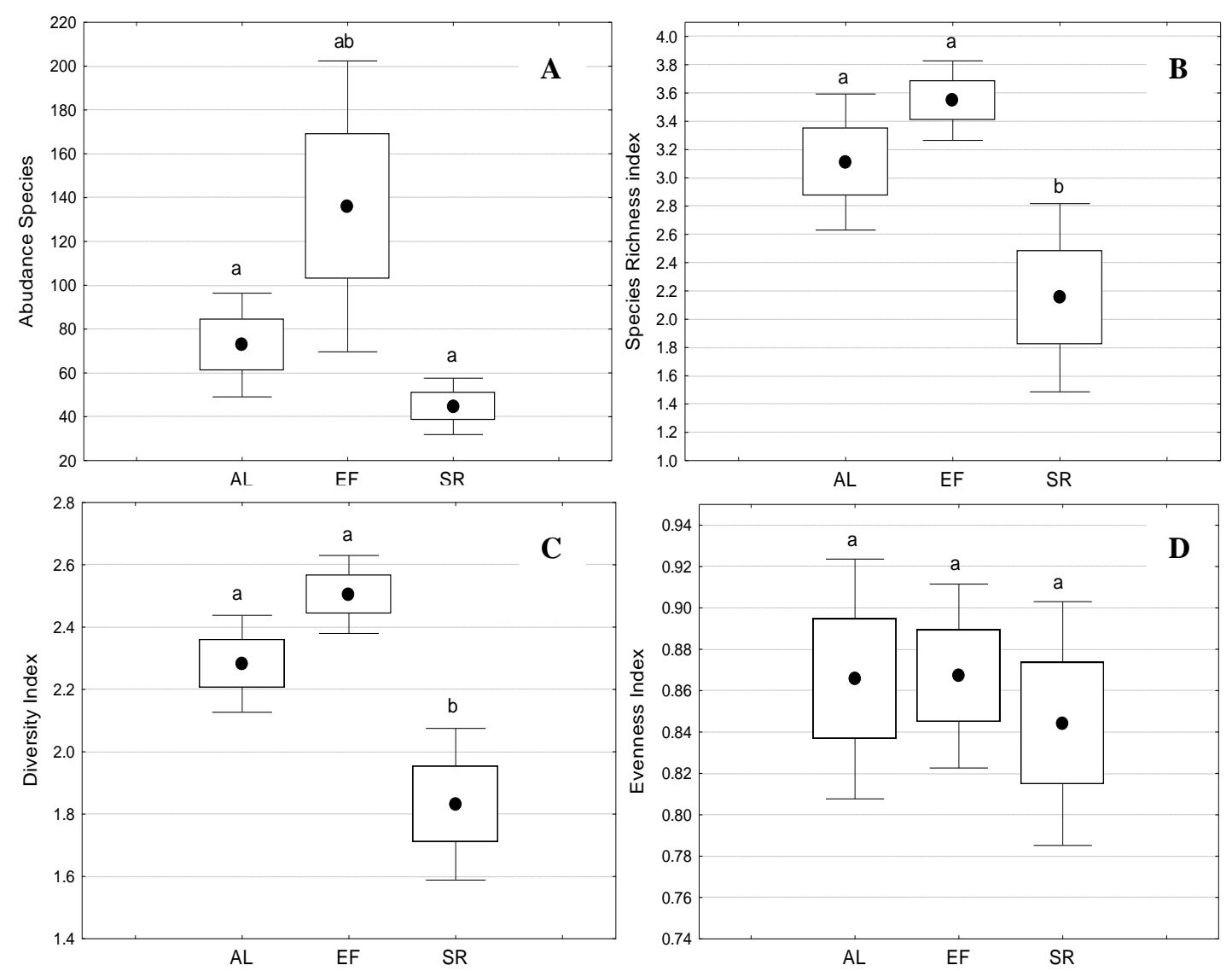

Figure 4. The influence of habitat types (A) abundance, (B) richness (C) diversity and (D) evenness species indexes in Talaud Islands, North Sulawesi, Indonesia. Note: AL: Farmland; EF: Edge of forest, SR: shrubland. The same letter in the same plot did not differ significantly according to Duncan's test at $95 \%$ confidence level

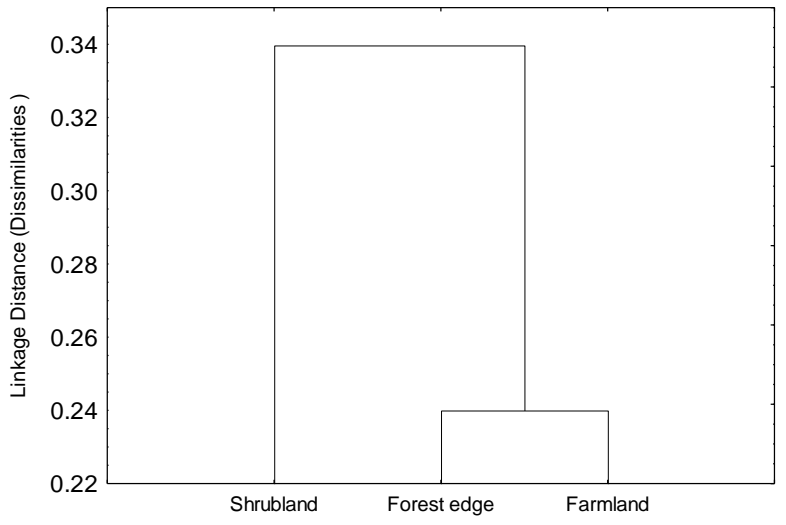

Figure 5. Dendrogram about butterfly community similarity among habitats in Talaud Islands, North Sulawesi, Indonesia

Table 4. Correlation coefficient among butterflies diversity and environmental factor

\begin{tabular}{lllll}
\hline Variable & Temp. & Humidity & Canopy & Altitude \\
\hline Abundance species & $-0.61^{*}$ & 0.57 & 0.58 & 0.36 \\
Richness index & $-0.86^{*}$ & $0.79^{*}$ & $0.85^{*}$ & $0.75^{*}$ \\
Diversity index & $-0.90^{*}$ & $0.83^{*}$ & $0.91^{*}$ & $0.85^{*}$ \\
Evenness index & -0.22 & 0.13 & 0.23 & 0.49 \\
\hline
\end{tabular}

Note: *Marked correlations are significant at $\mathrm{p}<.05000, \mathrm{~N}=12$
The correlation of butterfly species diversity with environmental factors showed that temperature factor was negatively correlated with species abundance $(-0.61)$, species richness index $(-0.86)$, and species diversity index $(-0.90)$ (Table 4). It showed that as the temperature gets lower, species abundance, species richness index, and species diversity index tended to increase. While, the richness index and diversity index of butterfly species were positively correlated with humidity, percentage of canopy closure, and altitude (Table 4).

\section{Discussion}

There is about 19,238 species butterfly in the world (Patil et al. 2017), so the number species of butterfly in Talaud Island is only $0.17 \%$ of species in the world. If compared to butterfly species in Indonesia, the species identified in this study were only $1.83 \%$ of the 1,750 butterfly species that are estimated to occur in Indonesia (Peggie 2014) and 5.71\% of the species living in Sulawesi Island. The number of butterfly species found in Sulawesi Island was around 560 butterfly species (Vane-Wright and de Jong 2003).

The number of butterfly species found in the Talaud Islands was higher than in other places, such as in Danum primary forest in Sabah (30 species) (Tanggah et al. 2004), Tangkuban Perahu and Situ Lembang in West Java (23 
species) (Subahar et al. 2007), Manado Tua Island in North Sulawesi (28 species) (Koneri and Saroyo 2012), Mantehage Island in North Sulawesi (19 species) (Lamatoa et al. 2013), and Perhentian Island and Bidong Island in Malaysia (27 species) (Rosmidi et al. 2017). However, some locations have the number of species higher than this study, for example: Ton Nga Chang Wildlife Sanctuary, Thailand (147 species) (Boonvanno et al. 2000), Mount Slamet, Central Java (99 species) (Widhiono 2015), Western Himalaya, India (75 species) (Uniyal 2007), Gunung Tumpa Botanical Forest Garden, North Sulawesi (50 species) (Tallei et al. 2015), Manembo-nembo Wildlife Reserve, North Sulawesi (44 species) (Koneri and Maabuat 2016), and Sangihe Islands (38 species) (Koneri and Nangoy 2019).

The difference in the number of butterfly species found is due to location and time period or season differences. High altitude, habitats tipe, and vegetation structural complexity each location was different. Also time periods such as dry and wet season extremely influence the microhabitat of butterfly. These all factors impact the difference in the number of butterfly species. In addition, different environmental disturbances in each habitat are also strongly suspected to have a significant effect on the number of butterfly species in each habitat.

The dominance of the family Nymphalidae in this study was due to this family of butterfly having the largest members and wider distribution compared to others (Rizal 2007). The food sources of Nymphalidae are plants from the families Annonaceae, Fabaceae, and Asteraceae (Peggie and Amir 2006) and in Talaud island all of those families plants were found in large number. The dominance of certain butterfly families in a region was influenced by the distribution of host plants and ecology (Amir et al. 2003; Panjaitan 2008). Some studies also reported that the Nymphalidae was predominantly found in several locations, such as Ujung Kulon National Park (New et al. 1987), Ton Nga Chang Wildlife Sanctuary in Songkhla Province, southern Thailand (Boonvanno et al. 2000), Aralam Wildlife Sanctuary in southwest India (Sreekumar and Balakhrisnani 2001), and Rawanwadi Reservoir in Bhandara, India (Patil et al. 2017), Halimun Salak National Park (Amir et al. 2003), forest area on Mount Slamet, Central Java (Widhiono 2004), Itapuã State Park, Brazil (Marchiori and Romanowski 2006), forest in protected area in western India (Joshi and Arya 2007), the Arfak Mountain Nature Reserve in Minyambouw District, Manokwari, West Papua (Panjaitan 2008), and Telaga Warna area in Cisarua, Bogor (Sari 2008).

The dominance of Nymphalidae is because of its ability to adapt to environmental conditions. The family also has the largest member species compared to other families and tends to be polyphage or able to fulfill its needs for host plants even though the main host plants are not primarily available. The population of butterflies from the family Nymphalidae does not merely depend on the availability of nectar because their food sources are also from rotten fruit and urine of other animals (Sari et al. 2013; Sarma et al. 2012; Lamatoa et al. 2013 )
Eurema tominia was the most commonly found butterfly species during the observation. At the time of observation, E. tominia flew low near the ground in an open area and only occasionally flew high in the trees. Adult E. tominia perched on the lower part of the leaf. According to Sreekumar and Balakrishnani (2001), E. tominia dominates various habitats because this species is polyphage eating a variety of food.. Food plants of $E$. tominia are plants from the families Caesalpiniaceae, Fabaceae, Euphorbiaceae, Asteraceae, and Mimosaceae (Braby 2000; Peggy and Amir 2006). During the observation, Eurema butterflies were often found perching on the perennial plant like shame plant (Mimosa pudica). Vane-Wrights and de Jong (2003) reported that Mimosa pudica is the food source of Eurema.

The most rarely found family was Hesperiidae. Might be it was caused by the dark brown colored wings, and this family often hides under the leaves. According to Sutra et al. (2012), the Hesperiidae prefers to hide under leaves, making them difficult to observe.

Compared to other habitats, forest edge was habitat that had the highest species abundance, species richness index, and species evenness index. In forest edge habitat, there are many flowering plants of the families Asteraceae, Fabaceae, Mimosaceae, Malvaceae, and Euphorbiaceae, which are food sources of butterflies. In the forest edge, there is also a river that can support the life of butterflies. River environment provides a mineral source for the butterflies. This mineral is usually obtained from the surface of rocks and soil on the banks of rivers. The banks of the river have diverse vegetation, sand, mud, rocks, and water that are able to attract more butterflies when they take water and nutrients from wet rocks, mud, and sand along the riverside (Van Vu and Quang Vu 2011). Knodel et al. (2004) reported that some butterfly species are attracted to water sources, such as mud puddles, wet and sandy areas, that provide sodium or minerals needed by butterflies to partake in puddling. During puddling, butterflies absorb sodium and protein, which play a role in meeting their nutritional needs. Puddling is exclusive behavior of the male butterfly. The collected sodium and minerals are then transferred by the male butterfly to female butterflies during the mating process (Boggs and Dau 2004).

Farmland and shrubland habitats had lower butterfly species diversity indices compared to the forest edge habitat. Farmland and shrubland are forests that have been intensively converted and managed. Shrubland habitat has different vegetation structures from the forest edge. Shrubland habitat is dominated by grasses, shrubs, and herbs. There are bare trees, the area is narrower than the forest, and there is no source of water as a mineral provider. The diversity of vegetation in a habitat, both as the source of food and shelter, can affect the diversity of butterfly species. Scoble (1992) reported that butterflies are highly dependent on the diversity of host plants and thus, providing a close relationship between the diversity of butterflies and their habitat conditions. Land conversion causes food sources of butterflies to diminish. According to Sodhi et al. (2004), conversion of natural habitat causes a 
decline in biodiversity. The results of the study by Kocher and Williams (2000) reported significantly decreased butterfly species diversity and richness indices in damaged habitats. The abundance of butterfly species has decreased in barren forests (Hill et al. 2003).

Some studies reported that the conversion of forests causes changes in the composition, abundance, and diversity of butterflies (Bobo et al. 2006; Koh 2007; Vu 2009). Butterfly species diversity tends to decrease in damaged forests compared to in undamaged forests (Brown 1996; Schulze et al. 2004; Fermon et al. 2005; Bobo et al. 2006; Vu et al. 2015). Butterflies have been reported to not live long in damaged habitats (Kunte 2001; Saikia et al. 2009).

The forest edge had the highest evenness index compared to other habitats. This finding meant that at the forest edge, no certain butterfly species dominated. According to Rahayuningsih et al. (2012), high species evenness index in an area shows that habitat in the area is more stable than habitats in other areas with low species evenness. The lowest evenness of butterfly species was at shrubland habitat. These findings indicated that there were several butterfly species that dominated in terms of the number of individuals per species. Four butterfly species were found in a large number in shrubland habitat i.e., Eurema tomina, Junonia hedonia intermedia, Orsotriaena medus, and Graphium agamemnon. According to Effendi (2009), if the butterfly species evenness index gets higher, the butterfly species are evenly distributed, and no dominance of certain butterfly species is found.

Temperature is a factor that influences activity, distribution, growth, and breeding of butterflies. The results of the correlation analysis showed that species abundance, species richness index, and species diversity index were negatively correlated with air temperature. The diversity index showed an increasing trend with decreasing temperature. Butterflies are poikilothermic organisms (Ramesh et al. 2010), their internal temperatures are greatly affected by the temperature of the environment, and thus, butterflies must be in an environment with appropriate conditions. The air temperature in shrubland was higher than it was in the forest edge. High temperature causes the volume of nectar secretion to decrease, so butterflies reduced their activities in that area or moved to warmer forest areas to save energy and reduce evaporation of body fluids (Efendi 2009).

Air humidity and canopy closure were positively correlated with butterfly species abundance, butterfly species richness index, and butterfly diversity index. This result indicated that butterflies preferred habitats that had high humidity, such as clear river banks or under trees. The measurements of air humidity and tree canopy found that the forest edge tended to have higher humidity compared to farmland and shrubland. The optimal humidity required by butterflies to breed is in the range of $84-92 \%$ (Borror et al. 1996). Tree canopy greatly affects the diversity of butterfly species because the canopy is shelter and food source of these butterflies. There are several butterfly species that live in habitats with thick canopies. There are also species that live in habitats with fewer canopies. Several studies have reported that butterflies are more commonly found in semi-closed or closed areas and natural habitats (Van $\mathrm{Vu}$ and Quang Vu 2011).

The analysis of habitat similarity index showed that the highest similarity composition of butterfly species was between forest edge and farmland. The community of butterfly species was strongly influenced by a rapid movement of butterflies to migrate from their habitat and thus, affecting the existence of a butterfly species. Community similarity index was also influenced by vegetation characteristics in all three habitat types. Although the structure of vegetation complexity in each habitat type was different, the species of family Nymphalidae is the dominant butterflies in all of the habitat types. Members of Nymphalidae have the ability to live in various types of habitats so that their area of distribution is wide and they are polyphagic. The similarity of butterfly community between habitats is highly dependent on the distance between one habitat and another, the same composition and structure of vegetation, and other environmental factors.

\section{ACKNOWLEDGEMENTS}

We would like to express our gratitude to the Directorate of Research and Community Service and Directorate General of Strengthening Research and Development of the Ministry of Research, Technology and Higher Education, Jakarta, Indonesia for funding this research through Competency-Based Research in Fiscal Year 2018. (No. 087/SP2H/LT/DRPM/2018).

\section{REFERENCES}

Abrol DP. 2012. Pollination Biology: Biodiversity Conservation and Agricultural Production. Springer, Heidelberg, Aguirre-Gutiérrez J, Marshall L, Wallisdevries M, van't Zelfde M, Villalobos-Arambula AR, |Boekelo B, Bartholomeus H, Franzen M, Biesmeijer JC. 2017. Butterflies show different functional and species diversity in relationship to vegetation structure and land use. Global Ecol Biogeogr 26: 1-12.

Amir MWA, Noerdjito WA, Kahono K. 2003. Butterflies (Lepidoptera) in Insects Mountain National Park Hazy Western Java. Biodiversity Conservation Project, Bogor.

Arya MK, Dayakrishnan, Chaudhary R. 2014. Species richness and diversity of butterflies in and around Kumaon University, Nainital, Uttarakhand, India. J Entomol Zool Stud 2: 153-159.

Bobo KS, Waltert M, Fermon H, Njokagbor J, Muhlenberg M. 2006. From forest to farmland: butterfly diversity and habitat associations along a gradient of forest conversion in southwestern Cameroon. J Insect Conserv 10: 29-42.

Boggs CL, Dau B 2004. A resource specialization in puddling Lepidoptera. Environ Entomol 33: 1020-1024.

Boonvanno K, Watanasit S, Permkam S, 2000. Butterfly diversity at ton Nga-Chang wildlife sanctuary, Songkhla Province, Southern Thailand. SciAsia, 26: 105-110.

Borror DJ, Triplehorn CA, Johnson NF. 1996. Introduction to the Study of Insects, 6th Edition. Saunders College Publishing, Ohio, USA.

Braby MF. 2000. The Butterflies of Australia: Their Identification, Biology and Distribution. CSIRO Publishing: Collingwood; 976 pp.

Brown KS. 1996. The use of insects in the study, conservation and monitoring of biological diversity in Neotropical habitats, in relation to traditional land use systems. In: Ae SA, Hirowatari T, Ishii M, Brower LP (eds.). Decline and Conservation of Butterflies in Japan 
III; Proceedings of the International Symposium on Butterfly Conservation. The Lepidopterological Society of Japan, Osaka, Japan.

Efendi MA. 2009. Diversity of Butterflies (Lepidoptera: Ditrysia) in "Corridor Forest", Gunung Halimun-Salak National Park, West Java. [Tesis]. School of Post Graduate Studies of Bogor Agricultural University. Bogor.

Fermon H, Waltert M, Larsen TB, Dall'Asta U, Muhlenberg M. 2005 Forest use and vertical stratification in fruit feeding butterflies of Sulawesi, Indonesia: impacts for conservation. Biodivers Conserv 14 333-350. Harmonis, Saud OR. 2017. Effects of habitat degradation and fragmentation on butterfly biodiversity in West Kotawaringin, Central Kalimantan, Indonesia. Biodiversitas18: 500-506.

Google Inc. 2019. Google Maps: Map of the study area in Talaud Islands, North Sulawesi, Indonesia. https://www.google.com/maps/@4.2247028,126.7630548,10z [18 July 2019]

Hill JK. 1999. Butterfly spatial distribution and habitat requirements in a tropical forest: impacts of selective logging. J Appl Ecol 36: 564-572.

Hill JK, Hamer KC, Dawood MM, Tangah J, Chey VK. 2003. Rainfall but not selective logging affect changes in abundance of a tropical forest butterfly in Sabah, Borneo. J Trop Ecol 19: 35-42.

Joshi PC, Arya M. 2007. Butterfly communities along altitudinal gradients in a protected forest in the Western Himalayas, India. Nat His J Chulalongkorn Univ 7: 1-9.

Kannagi A, Sivakumar V, Santhi V. 2016. Diversity of dragonflies (Insecta: Odonata) in a deciduous forest of Thoothukudi District, Tamil Nadu, South India. Int J Environ Prot Policy 4: 58-63.

Kocher SD, Williams EH. 2000. The Diversity and abundance of North America Butterflies, vary with habitat disturbance and geography. J Biogeogr 27: 785-794.

Koh LP. 2007. Impacts of land use change on South-east Asian forest butterflies: a review. J Appl Ecol 44: 703-713.

Koneri $R$, Maabuat PV. 2016. Diversity of butterflies (Lepidoptera) in Manembo-Nembo Wildlife Reserve, North Sulawesi. Pak J Biol Sci 19: $202-210$

Koneri R, Nangoy MJ. 2019. Butterfly community structure and diversity in Sangihe Islands, North, Sulawesi, Indonesia. Appl Ecol Env Res 17: 2501-2517.

Koneri R, Saroyo. 2012. Distribution and diversity of butterfly (Lepidoptera) in Manado Tua Mountain, region of Bunaken National Marine Park, North Sulawesi, Indonesia. Jurnal Bumi Lestari 12: 357 365 .

Knodel JJ, Fauske GM. 2004. Butterfly Gardening in North Dakota.North Dakota State University. Fargo North Dakota.

Krebs CJ. 1999. Ecological Methodology. Second Ed. Addison-Wesley, Menlo Park.

Kunte K. 2001. Butterfly diversity of Pune city along the human impact gradient. Journal of Ecology Society 13: 40-45.

Lamatoa DC, Koneri R, Siahaan R, Maabuat PC. 2013. Population of butterflies (Lepidoptera) in Mantheage Island, North Sulawesi. Jurnal Ilmiah Sains 13: 52-56.

Lewis TO. 2001. Effect of experimental selective logging on tropical butterflies. Conserv Biol 15: 389-400.

Ludwig JA, Reynolds. 1998. Statistical Ecology; a Primer on Methods and Computing. John Wiley and Sons, New York

Magurran AE. 1988. Ecological Diversity and its Measurements. Croom Helm, London, pp: 179.

Magurran AE. 2004. Measuring Biological Diversity. Wiley-Blackwell, Malden, USA

Marchiori MO, Romanowski HP. 2006. Species composition and die variation of a butterfly taxocene (Lepidoptera, Papilionoidea and Hesperioidea) in a Restinga forest at Itapua State Park, Rio Grande do Sul, Brazil. Revista Brasileira de Zoologia 23: 443-454.

Martin P, Bateson P. 1993. Measuring Behavior: An Introductory Guide. Cambridge University Press, Cambridge, England.

Martínez-Adriano CA, Díaz-Castelazo C, Aguirre-Jaimes A. 2018. Flower-mediated plant-butterfly interactions in an heterogeneous tropical coastal ecosystem. PeerJ. 6: 1-22.

Merckx T, Huertas B, Basset Y, Thomas J. 2013. A Global Perspective on Conserving Butterflies and Moths and Their Habitats. In: Macdonald DW, Willis KJ (eds.), Key Topics in Conservation Biology 2. WileyBlackwell, Chichester.

Miller JC, Hammond PC. 2007. Butterflies and Moths of Pacific Northwest Forests and Woodlands: Rare, Endangered, and Management-Sensitive Species. FHTET-2006-07. Department of
Agriculture, Forest Service, Forest Health Technology Enterprise Team. Morgantown, VW, U.S.

New TR, Bush MB, Sudarman HK. 1987. Butterflies from the Ujung Kulon National Park, Indonesia. J Lepid Soc 41: 29-40.

Noerdjito WA, Aswari P. 2003. Methods of Surveying and Monitoring Animal Populations: 4th Series: Papilionidae Butterflies. Center for Biological Research and Development. LIPI, Bogor.

Ohsawa M. 2005. Species richness and composition of Curculionidae (Coleoptera) in a conifer plantation, secondary forest and old-growth forest in the central Mountainous region of Japan. Ecol Res 20: 632645.

Panjaitan R. 2008. Distribution of butterflies (Superfamily Papilionoidae: Lepidoptera) in Minyambou, Manokwari Arfak Mountains Nature Reserve, West Papua. Berkala Ilmu Biologi 7: 11-16.

Patil KG, Kanekar A, Shende VA, Bhimrao US. 2017. A report on butterfly diversity of Rawanwadi Reservoir, Bhandara (Maharashtra), India. Arthropods 6: 21-28.

Peggie D, Amir M. 2006. Practical Guide to the Butterflies of Bogor Botanic Garden. Pusat Penelitian Biologi, LIPI, Cibinong, Indonesia.

Peggie D. 2011. Precious and protected Indonesian Butterflies. PT. Binamitra Megawarna. Jakarta

Peggie D. 2014. Mengenal Kupu-kupu. Pandu Aksara Publishing. Jakarta. [Indonesian]

Pollard E. 1977. A method for assessing changes in the abundance of butterflies. Biol Conserv 12: 115-134.

Posha, RMC, Sodhi NS 2006. Effects of anthropogenic land use on forest birds and butterflies in Subic Bay, Philippines. Biol Conserv 129: 256-270.

Rahayuningsih M, Oqtafiana R, Priyono B. 2012. Diversity of butterfly species in the superfamily Papilionoidae at Banyuwindu Hamlet, Limbangan Village, LimbanganDistrict, Kendal Regency. Jurnal MIPA 35: 11-20.

Ramesh T, Hussain KJ, Satpathy KK, Selvanayagam M. 2012. A note on annual bidirectional movement of butterflies at South-Eastern Plains of India. Res Zool 2: 1-6.

Rizal S. 2007. Population butterfly in Rimbo Panti Nature Reserve and Lubuk Minturun West Sumatera. Mandiri 9: 177-184.

Rosmidi FH, Zahidin MA, Adanan A, Azizah A, Pesiu E, Abdullah MT. 2017. Checklist of butterflies in Pulau Perhentian and Pulau Bidong, Terengganu. J Sustain Sci Manag 12: 40-48.

Sari YK. 2008. Biodiversity of Butterflies in Lembah Cilengkrang Gunung Ciremai National Park. [Hon. Thesis]. Department of Biology, Bogor Agricultural University, Bogor.

Sari EFW, Soekardi H, Nukmal N, Martinus. 2013. Diversity of Nymphalidae in Tegal Island and Puhawang Kecil Island, Lampung Bay. Conference paper: Seminar Nasional Sains \& Teknologi V Lembaga Penelitian Universitas Lampung, Bandar Lampung.

Saikia KM, Kalita J, Saikia PK. 2009. Ecology and conservation needs of Nymphalid butterflies in disturbed tropical forest of Eastern Himalayan Biodiversity Hotspot, Assam, India. J Biodiv Conserv 1: 231-250.

Sarma K, Kumar A, Devi A, Mazumdar K, Krishna M, Mudoi P, Das N. 2012. Diversity and habitat association of butterfly species in Foothills of Itanagar, Arunachal Pradesh, India. Zool 1: 67-77.

Schulze CH, Steffan-Dewenter I, Tsharntke T. 2004. Effect of land use on butterfly communities at the rainforest margin: a case study from Central Sulawesi. In: Gerold G, Fremerey M, Guhardja E (eds). Land Use, Nature Conservation and the Stability of Rainforest Margins in Southeast Asia. Springer-Verlag, Berlin.

Scoble MJ. 1992. The Lepidoptera: Form, Function, and Diversity. Oxford University Press, Oxford.

Sodhi NS, Koh LP, Brook BW, Nge PKL. 2004. Southeast Asian biodiversity: an impending disaster. Trends Ecol Evol 19: 654-660.

Sreekumar PG, Balakrishnan M. 2001. Habitat and altitude preferences of butterflies in Aralam Wildlife Sanctuary, Kerala. J Trop Ecol 42: 277 281.

StatSoft. 2001. Stastistica for Windows. Ver. 6.0, StatSoft Inc., Tulsa, OK, USA..

Subahar TSS, Amasya AF, Choesin DN. 2007. Butterfly (Lepidoptera: Rhopalocera) distribution along an altitudinal gradient on Mount Tangkuban Parahu, West Java, Indonesia. Raffles Bull Zool 55: 175178.

Sutra NSM, Dahelmi S, Salmah S. 2012. Butterflies species (Rhopalocera) in Tanjung Balai Karimun, Kabupaten Karimun Regency, Riau Islands. Jurnal Biologi Univ Andalas 1: 35-44. 
Tabadepu H, Buchori D, Sahari B. 2008. Butterflies record from Salak Mountain, Indonesia. Jurnal Entomologi Indonesia 5: 10-16.

Tallei TE, Nangoy MJ, Koneri R, Saroyo. 2015. Biodiversity assessment of Mt. Tumpa Forest Park, North Sulawesi, Indonesia. Asian J Biodiv 6: 1-21.

Tangah J, Hill JK, Hamer KC, Dawood MM. 2004. Vertical distribution of fruit-feeding butterflies in Sabah, Borneo. Sepilok Bull 1: 17-27.

Thomas JA. 2005. Monitoring change in the abundance and distribution of insects using butterflies and other indicator groups. Phil Trans R Soc B Biol Sci 360: 339-357.

Tsukada E. 1982. Butterflies of the South East Asian Islands: Papilionidae. Palapa Co. Ltd., Minatok, Tokyo.

Tsukada E, Nishiyama Y. 1981. Butterflies of the South East Asian Island: Pieridae-Danaidae, Part II. Palapa Co. Ltd., Minatok, Tokyo.

Tsukada E, Nishiyama Y. 1982. Butterflies of the South East Asian Island: Part III Satyridae-Lybytheidae. Palapa Co. Ltd., Minatok, Tokyo.

Tsukada E, Nishiyama Y. 1985. Butterflies of the South East Asian Island: Part IV Nymphalidae (I). Palapa Co. Ltd., Minatok, Tokyo.
Tsukada E, Nishiyama Y. 1991. Butterflies of the South East Asian Island: Part V Nymphalidae (II). Palapa Co. Ltd., Minatok, Tokyo.

Uniyal VP, 2007. Butterflies in the great Himalayan conservation landscape in Himachal Pradesh, Western Himalaya. Entomon 32: 119-127.

Vane-Wright RI, de Jong R. 2003. The butterflies of Sulawesi: Annotated checklist for a critical island fauna. Zoologische Verhandelingen 343: 3-267.

Vu VL. 2009. Diversity and similarity of butterfly communities in five different habitat types at Tam Dao National Park, Vietnam. J Zool 277: 15-22.

Van Vu L, Quang Vu C. 2011. Diversity pattern of butterfly communities (Lepidoptera: Papilionoideae) in different habitat types in a tropical rain forest of Southern Vietnam. ISRN Zool 2011: 1-8.

Vu VLTC, Bonebrake MQ, Vu NTN. 2015. Butterfly diversity and habitat variation in a disturbed forest in Northern Vietnam. Pan-Pacific Entomol 91: 29-38.

Widhiono I. 2015. Diversity of butterflies in four different forest types in Mount Slamet, Central Java, Indonesia. Biodiversitas 16: 196-204. 